\author{
International Journal of Global Accounting, Management, Education, \\ and Entrepreneurship (IJGAME 2) \\ URL : https://jurnal.stiepemuda.ac.id/index.php/ijgame2 \\ P- ISSN : 2723-2948 \\ E-ISSN : 2723-2204
}

\title{
THE EFFECT OF ENTREPRENEURSHIP EDUCATION AND EMOTIONAL INTELLIGENCE OF INTEREST THROUGH ATTITUDE ENTREPRENEURSHIP GENERATION Y
}

\author{
Prevista Fakhrun Nisa ${ }^{1}$, Syamsul Arifin ${ }^{2}$ \\ Universitas Negeri Surabaya ${ }^{1}$, Sekolah Tinggi Ilmu Ekonomi Pemuda ${ }^{2}$ \\ Email: previstanisa@mhs.unesa.ac.id ${ }^{1}$, syamsularifin.stiepemuda@gmail.com ${ }^{2}$
}

\begin{abstract}
Entrepreneurship education not only provides a theoretical foundation of the concept of entrepreneurship but to shape attitudes, behaviors, and thought patterns (mindset) of an entrepreneur (entrepreneur). This is an investment in human capital to prepare the generation $\mathrm{Y}$ in starting a new business through the integration of experience, skills and knowledge necessary to develop and expand a business. Entrepreneurship education can also increase the interest of generation $\mathrm{Y}$ to choose entrepreneurship as a career option in addition to career options become private sector employees, civil servants or employees of state-owned enterprises which can significantly drive attitudes, behaviors, and interests toward entrepreneurship.
\end{abstract}

Keywords: Entrepreneurship Education, Emotional Intelligence, Interests Entrepreneur, Entrepreneur Attitude, Generation Y.

\section{INTRODUCTION}

Government will continue to increase the number of college graduates each year. Yet on the other hand, the absorption of graduates in Indonesia has been slow. Based on data from the Central Bureau of Statistics, Labor Force Indonesia in February 2015 as many as 128.3 million people, increased by 6.4 million people, compared to August 2014 increased by 3.0 million people compared to February 2014. The working population in February 2015 as many as 120.8 million people, an increase of 6.2 million compared to August 2014 increased by 2.7 millions compared to February 2014. Unemployment rate (TPT) in February 2015 decreased by 5.81 percent compared to TPT August 2014 (5.94 percent), and increased compared to TPT February 2014 (5.70 percent).The gap due to the mismatch between the needs of the workforce competencies with the competencies of graduates. One of the real problems which this portrait is the number of job seekers who apply to the academic requirements have met the standard criteria, but after entering the working world is they do not understand and have the skills in the field of work. Another constraint is the low capacity owned soft-skills job seekers. This time not only the ability of hard-skills required by the world of work but also soft-skills. Factors that gives success in the world of work is soft-skills (40\%), networking (30\%), hard-skills (20\%), and financial (10\%) (Dekdiknas, 2007).

Results of research in developed countries shows that the initiative, ethics / integrity, critical thinking, willingness to learn, commitment, motivation, spirit, reliable, 
oral communication skills, and creative are 10 attributes the dominant soft-skills required by the world of work. It reinforced the opinion Wibowo (2011) explains that in order for a country to prosper is required at least $2 \%$ of the population who become entrepreneurs. Barnawi (2012: 62) argues that entrepreneurship education aims to form the whole Indonesian people who have the understanding and skills as an entrepreneur. All universities in Indonesia have incorporated entrepreneurship courses into their curriculum as one of the principal subjects to be taken by all students. Entrepreneurship education not only provides a theoretical foundation of the concept of entrepreneurship but to shape attitudes, behaviors, and thought patterns (mindset) of an entrepreneur (entrepreneur). This is an investment in human capital to prepare the generation $\mathrm{Y}$ in starting a new business through the integration of experience, skills and knowledge necessary to develop and expand a business. Entrepreneurship education can also increase the interest of generation $\mathrm{Y}$ to choose entrepreneurship as a career option in addition to career options become private sector employees, civil servants or employees of state-owned enterprises which can significantly drive attitudes, behaviors, and interests toward entrepreneurship. Entrepreneurship education can shape the mindset, attitude, and behavior on the generation $\mathrm{Y}$ being an entrepreneur (entrepreneur) true that directs them to choose entrepreneurship as a career option. But sometimes students find it difficult to learn to become a businessman in fact, that should make up the character of an independent by growing entrepreneurial spirit in order to have a character who is always confident, not afraid of a challenge, have creative ideas and innovative ideas to take advantage of opportunities that exist in efficiently to achieve the objectives of value and sustainable results. Knowledge in the form of intelligence quotient (IQ) obtained by the generation $\mathrm{Y}$ dibangku school is very important, in fostering an entrepreneurial spirit in addition to knowledge should also be reinforced by several factors such as emotional intelligence (EQ).

Emotional intelligence is needed by the $\mathrm{Y}$ generation in the world of work, because there will be many demands and problems that arise in the workplace. Employment is one of the problems that always arise the first time when the generation Y completing his education and is also a problem that the phenomenon in Indonesia. Not least for recent graduates who are expected to take part in accordance with the field of education pursued. It is strengthened with the opinion of Goleman (2003), said that emotional intelligence is the ability to motivate yourself and endure frustrated impulse control and not exaggerating pleasure, set the mood and keep stress free, do not cripple the ability to think, empathize and pray, That is to say emotional intelligence has an important role in achieving personal and professional success. According to Goleman (2003), concludes emotional intelligence is a bridge between what we know and what we will do. The more emotionally intelligent person skilled he will do whatever he know to be true (Segal et al., 2005). Similarly, Sasani study (2012) found the effect of emotional intelligence on the interest in entrepreneurship.

The fact and the circumstances that may lead to difficulty may be regarded as pressure, load, or challenge for the prospective graduate. Required an intelligence and good qualities to address these problems, so it gets success in taking decisions in the 
selection of his career. Because in such conditions is not enough intelligence, but emotional intelligence is also required. Emotional intelligence needed to address the problems faced by prospective new scholars such as worry and fear do not get a job, find a job have less information and feels unable to adapt to a job. Since the problem of selection and career preparation is one of the important developmental tasks and can affect a person's whole future, so if the prospective graduate successfully complete the development tasks can make happy. Conversely, if one fails, it could make unhappy, resistance arises from the community, and have difficulty in the task of further developments (Hurlock 1980).

Mental attitude or readiness to jump start new businesses underlying the emergence of interest in entrepreneurship. Kamsir (2013: 19) mengemuakakan that simple terms the meaning of the entrepreneur (entrepreneur) is a spirited person who took a risk to open a business in a variety of occasions. Brave souls take risks means independent minded and dare to start a business without fear or anxiety overwhelmed even in uncertain conditions. According Slameto (2003) attitude is something that is learned and how individuals react to the situation and determine what to look for people in life. The study results Firmansyah (2016) found that the entrepreneurial attitude positive effect on interest in entrepreneurship. Based on the description in the above paragraph, researchers are encouraged to examine more in a study entitled "Effect of Entrepreneurship Education and Emotional Intelligence to Interests entrepreneurship through entrepreneurship attitude Generation Y".

In the study of this theory will be discussed description of the theory of the concept of entrepreneurship, Entrepreneurship Education (Entrepreneurship Education), EQ (Emotional Intelligence), Attitudes Entrepreneurship (Entrepreneurial Attitude) and Interest Entrepreneurship (Entrepreneurial Intention).

1) The Concept of Entrepreneurship (Entrepreneurship)

According to Santoso (2012: 150-151) Entrepreneurship has become a topic of conversation was warm enough among economists, leaders, policy makers, academics, and even students. Since the early 1980s, entrepreneurship thriving in almost all countries. Entrepreneurship is considered as one of the best economic development strategy to develop a country's economic growth and maintain the competitiveness of the country in the face of increasing globalization trend. Thus, entrepreneurship has a very important role for a country, especially as a driver of economic growth in each country. The term entrepreneur and entrepreneurship was introduced by Richard Cantillon, a French economics of Irish descent (Winardi, 2015: 1). Definition of entrepreneurship often mentioned by economists. Sagiri and Appolloni (2009: 65) defines entrepreneurship as follows: "Entrepreneurship is the process of creating something new with value by devoting the Necessary time and effort, assuming the Accompanying financial, psychic, and social risks, and receiving the the resulting rewards of monetary and personal satisfaction and independence ". The above definition implies entrepreneurship is a behavior that includes: (a) initiatives; (B) the ability to manage human resources or natural resources in a variety of situations to create profits; and (c) take risks. In other words, it can be concluded that entrepreneurship is the process of 
creating something new by using time and activities with the capital and the risks and receive remuneration and the satisfaction and personal freedom (Vemmy, 2012: 119).

2) Entrepreneurship Education (Entrepreneurship Education)

Bieber et al. (2012) states that entrepreneurship education can shape the mindset, attitudes, and behaviors in students being a true entrepreneur that led them to choose entrepreneurship as a career option. Entrepreneurial learning method must be able to transfer not only knowledge and skills but also the ability to make a real effort, and obtained spirit of entrepreneurship itself (Siswadi, 2013). Entrepreneurship education is highly dependent on the receipt of an entrepreneurial mindset at universities and the creation of entrepreneurial environment in and around the University (Varblane et al., 2010). It can be concluded entrepreneurship education and training which is owned by an entrepreneur can influence future behavior and attitude of students to become entrepreneurs and develop entrepreneurship and good business, especially the younger generation through universities and colleges (Packham et al., 2010).

3). EQ (Emotional Intelligence)

Emotional intelligence is the ability of a person more self-motivation, resilience in the face of failure, control emotions and delay gratification, and set the state of the soul (Goleman, 2003). Goleman (2003) emotional intelligence divides into five parts, namely the three components in the form of emotional competence (selfknowledge, self-control and motivation) and the two components in the form of social competence (empathy and social skills). This ability is different from each other and complement each other with pure academic ability measured by IQ. Good emotional intelligence can be seen from the ability to know yourself, control yourself, motivate yourself, empathy, and social skills.

4). Attitude Entrepreneurship (Entrepreneurial Attitude)

Schiffman and Kanuk (1994: 249) defines attitude as "an expression of inner feelings that reflect Whether a person is or infavorably favorably predisposed to some object". Loudon and Della Bitta (1993: 423) suggests the attitude is "an enduring organization of motivational, emotional, perceptual, and cognitive process with respect to some aspect of the individual world". In line with the above definition, Sumarwan (2004: 136) states that "attitude as a person's overall evaluation of a concept". In the context of entrepreneurship, attitude towards the behavior (attitude) is defined by Linan, Cohard and Cantuche (2011: 195) as "the degree to the which the individual holds a positive or negative personal valuation about being an entrepreneur. Meanwhile, Assael in Andika and Madjid (2012: 192) considers the attitude as a learned tendency to respond to objects consistently, both in taste likes and dislikes. Based on the above definition, it can be concluded that the attitude is a learned tendency to respond or receive stimulation of the object consistently, both in taste likes and dislikes.

Thus, the attitude of entrepreneurship can be defined as the tendency to react affectively in response to the risks that would be faced in a business. Entrepreneurship attitude was measured with a scale entrepreneurship attitude in 
Andika and Madjid (2012: 192) with indicators, which are interested in business opportunities, creative thinking, positive outlook regarding business failure, leadership potential and like challenges.

5). Interests Entrepreneurship (Entrepreneurial Intention)

Definition of entrepreneurial intentions (entrepreneurial intention) often mentioned by experts. Lee Wei Ni, et.al (2012: 18) defines an entrepreneurial intention as "the willingness of individuals to perform entrepreneurial behavior, to engage in entrepreneurial action, to be self-employed, or to establish new business". Linan, Cohard and Cantuche (2011) suggested the entrepreneurial intention as "the effort that the person will make to carry out the entrepreneurial behavior". Douglas and Fitzzimmon (in Zain, Akram and Ghani, 2010: 36) reveals the definition of entrepreneurial intention as "the action of an individual's attitudes towards the outcomes of actions and individuals that self-efficacy". Meanwhile, Zain, Akram and Ghani (2010: 36) states that "entrepreneurial intention Often involves inner guts, ambition and the feeling to stand on one's feet".

Interest in entrepreneurship can be defined as well as the process of finding information that can be used to achieve the establishment of a business (Andika, Manda, and Iskandarsyah, 2012: 192). Meanwhile, entrepreneurial intentions expressed by Ramayah and Aaron (in Andika and Madjid, 2012: 192) as the tendency of students to act self-employment by creating new products through business opportunities and taking risks. Entrepreneurial intentions can be measured using a scale entrepreneurial intention (Linan \& Chen, 2006: 20). Lee Wei Ni, et.al (2012: 133-136) with the following indicators: becoming an entrepreneur, prefer to be an entrepreneur rather than to be an employee, have thought very seriously, make every effort to start and to start a firm some day. Conceptual Framework Research. Based on the theoretical basis of the influence of Entrepreneurship Education (Entrepreneurship Education) and EQ (Emotional Intelligence) Attitudes towards entrepreneurship (Entrepreneurial Attitude) and Interest Entrepreneurship (Entrepreneurial Intention), it can be arranged an a frame-conceptual in this study are as follows:

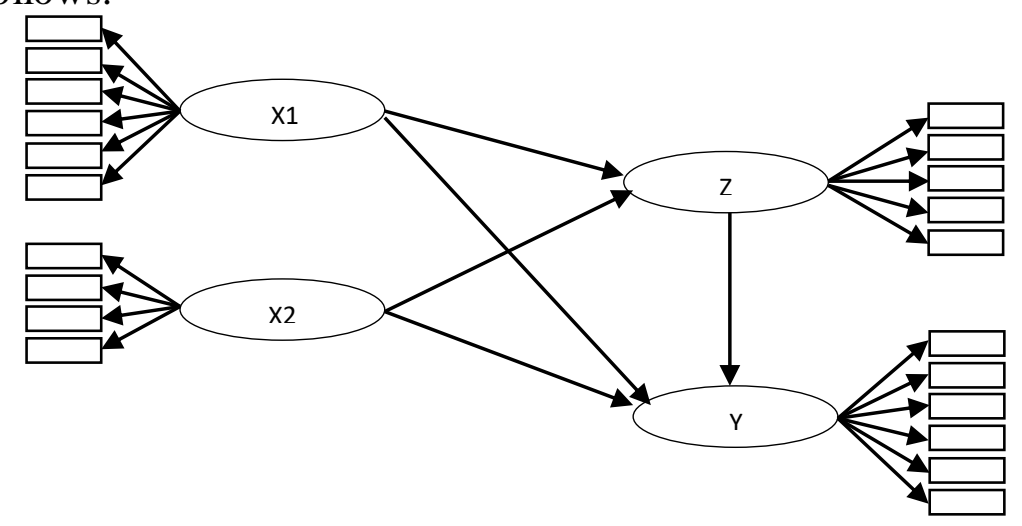

Figure: Conceptual Framework Research 
The hypothesis is a temporary answer to the problem is still a presumption because they still have to be verified. Based on the theoretical framework and the process of thinking, then proposed the research hypothesis as follows:

H1: Suspected entrepreneurship education significantly influence entrepreneurial attitudes generation $\mathrm{Y}$

$\mathrm{H} 2$ : Suspected emotional intelligence significantly influence entrepreneurial attitudes generation $\mathrm{Y}$

H3: Suspected entrepreneurship education significantly influence the interest in entrepreneurship generation Y

H4: Suspected emotional intelligence significantly influence the interest in entrepreneurship generation Y

H5: Suspected entrepreneurship attitude significantly influence the interest in entrepreneurship generation Y

\section{RESEARCH METHODS}

This study uses a positivist or scientific approach, because this research aims to identify causal relationships that describe the pattern of behavior of the elements in the organization and to test existing theories by formulating the research hypothesis. As mentioned by Popper in Henn et al., (2009: 14) that the positivist approach has two characteristics that emphasize the general theory (theory) in the case of a special nature (case); and the restriction criteria (demarcation) is clear, so the emphasis on what can be measured, not on observable. In addition this study was designed to address problems that have been formulated, the objectives to be achieved and to test the hypothesis.

This study used a survey method by spreading the questionnaire in order to obtain information, to answer the problems are formulated, the objectives to be achieved, as well as hypotheses to be tested based on quantitative data obtained from the measured data.

The approach used in this study is the quantitative approach. Analyzed using Structural Equation Modeling (SEM) to analyze the influence of Entrepreneurship Education and Emotional Intelligence to the interest in entrepreneurship through entrepreneurship attitude on generation $Y$. In this research, there are two independent variables namely Entrepreneurship Education $\left(\mathrm{X}_{1}\right)$, Emotional Intelligence $\left(\mathrm{X}_{2}\right)$ and the dependent variable is the interest in entrepreneurship (Y) and an intervening variable is the attitude to entrepreneurship (Z). Two independent variables $\left(\mathrm{X}_{1}, \mathrm{X}_{2}\right)$ are associated with the dependent variable $(Y)$ and the intervening variables $(Z)$ with a pattern of relationships: 1) the relationship between the variables Entrepreneurship Education $\left(\mathrm{X}_{1}\right)$ with interest in entrepreneurship (Y), 2) the relationship between Emotional Intelligence $\left(X_{2}\right)$ with interest in entrepreneurship (Y), 3) the relationship between the variables Entrepreneurship Education $\left(X_{1}\right)$ with the attitude to entrepreneurship $\left.(Z), 4\right)$ the relationship between Emotional Intelligence $\left(X_{2}\right)$ with an attitude of entrepreneurship $\left.(Z), 5\right)$ the relationship between attitudes to entrepreneurship $(Z)$ with interest in entrepreneurship (Y). 
In this study, used a survey method by spreading the questionnaire in order to obtain information, answer the problems are formulated, the objectives to be achieved as well as hypotheses to be tested based on quantitative data obtained from the measured data.

Operational Definitions

Education Kewirausahaanmerupakan as systematic training and instruction which sends entrepreneurial knowledge and skills development in students (CELCEE, 1999) .Indikator measurement Entrepreneurship Education with reference Pulka study (2015): a. Entrepreneurship education has an impact on my interest to become entrepreneurs; b. I really want to start my own business; c. Having your own business is very interesting and important to me; d. I can not imagine working for someone else; e. I'm interested to immediately start your own business; and f. I have the necessary skills to identify business opportunities.

The population is a combination of all the elements that have a similar set of characteristics that includes the universe (Malhotra, 2009: 364). In this study, the population is a whole generation Y (born 1977-1999) who has experience in the field of entrepreneurship. The sample is part of the number and characteristics possessed by the population, the sample taken from the population should be rigorously representative or represent (Sugiyono, 2012: 62). The sampling technique used in this research is proportional random sampling.

Proportional random sampling is a sampling technique of members of the sample of the population was randomly without regard to strata that exist in the population (Sugiyono, 2012: 82). SEM (Structural Equation Modeling), the sample size has an important role in the estimation and interpretation of the results of the calculation of SEM. SEM does not use the scores of individual data collected, SEM only uses the covariance matrix of sample data as input to generate an estimated population covariance matrix. So in this case, individual observation still be used, but these inputs will be converted into a covariance matrix or correlation matrix prior to estimation. This is because the focus of the SEM is not on individual data but on a pattern of relations between the respondents (Ferdinand 2002: 50).

In this study, the number of indicators used are as many as 21 indicators. Therefore the number of samples required is 21 x $5=105$ samples. Researchers add 5 samples were found to comply with the criteria set by the researchers. Based on this, the samples used in this study there were 100 respondents generation Y.

SEM (Structural Equation Modeling) using the application program AMOS 7.0. The stages of the SEM analysis.

\section{RESULTS AND DISCUSSION}

Validity test is intended to determine whether the statements in the questionnaire is quite representative. Validity test is done by using confirmatory factor analysis on each of the latent variables namely Entrepreneurship Education $\left(\mathrm{X}_{1}\right)$, Emotional Intelligence $\left(\mathrm{X}_{2}\right)$, Attitudes Entrepreneurship $(\mathrm{Z})$ and the interest in entrepreneurship (Y) with the help of 18 AMOS program. 
1) Entrepreneurship Education $\left(X_{1}\right)$

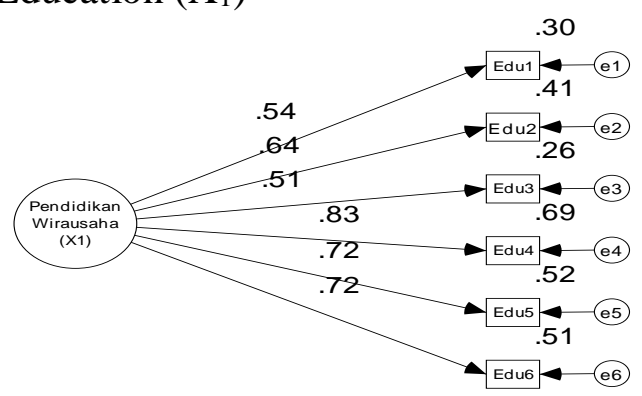

Figure:

Test Convergent ValidityPendidikan Entrepreneurship $\left(\mathrm{X}_{1}\right)$

Source: Appendix 3, the data is processed

Based on factor analysis in Figure: Entrepreneurship education has an impact on my interest in becoming entrepreneurs (Edu1); b. I really want to start my own business (Edu2); c. Having your own business is very interesting and important to me (Edu3); d. I can not imagine working for someone else (Edu4); e. I am interested in starting my own business soon (Edu5); and f. I have the necessary skills to identify business opportunities (Edu6) have convergent validity above 0.5 . This means that four factors may be eligible for a variable form of Entrepreneurship Education.

2) Emotional Intelligence $\left(X_{2}\right)$

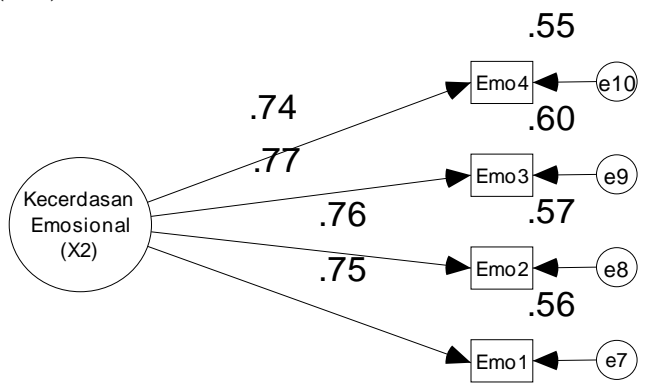

Figure:

Test Convergent Emotional validityKecerdasan (X2)

Source: Appendix 3, the data is processed

Based on Figure from 3 indicators tested, all four indicators: a. Self-awareness (Awareness); b. Self-control (Setting Yourself); c. Social Consciousness (Social Skills); and D. Management of relations (Relationship Management), convergent validity showed results above 0.5 . This means that seven of these factors meet the requirements for forming variable Emotional Intelligence.

3) The attitude of Entrepreneurship (Z) 


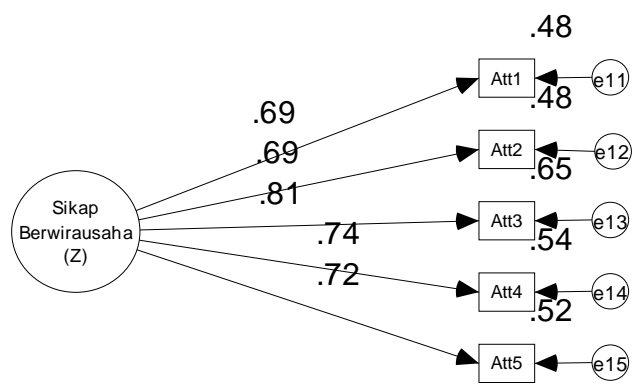

Figure: Convergent Validity Test Attitudes Entrepreneurship (Z)

Source: Appendix 3, the data is processed

The results of the factor analysis in Figure 4.3 shows that all the indicators of attitudes to entrepreneurship, namely: a) For me to be an entrepreneur provides many benefits than losses (Att1), b) A career as a businessman interested me (Att2), c) If I have an opportunity and a source of income (Att3), I want to start a business, d) Being an entrepreneur gives great satisfaction for me (Att4), e) Among the various options, I prefer to be an entrepreneur (Att5), have convergent validity above 0.5 . Then all the indicators in the variable Berwirausahamemenuhi attitude indicator requirements and can be said to represent or form variables entrepreneurship attitude.

4) Interest in entrepreneurship (Y)

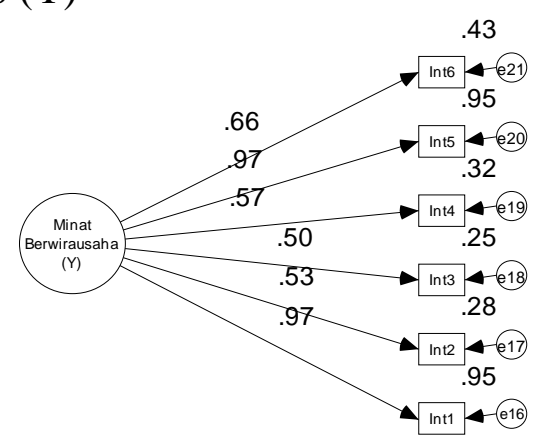

Figure: Test Convergent ValidityMinat entrepreneurship (Y)

Source: Appendix 3, the data is processed

Based on factor analysis in Figure 4.4, is known indicator forming Interests entrepreneurship are as follows: a) I am ready to do apapu in order to become an entrepreneur (INT1), b) My dream of becoming an entrepreneur professional (int2), c) I will try initiate and lead a self-owned enterprise (Int3), d) I was determined to create a company in the future (Int4), e) I have a seriousness of starting a company (Int5) and f) I am interested in starting a company (Int6) .It convergent validity above 0.5 . This means that these five factors meet the requirements for forming a variable interest in entrepreneurship. The second test used in this study is to test the reliability construct. Variables tested were forming an indicator variable that has more than 1 . construct reliability test results can be seen in Table 4.11 describes the construct reliability of latent variables of the study include: Entrepreneurship Education, Emotional Intelligence, Entrepreneurship Attitudes and Interests entrepreneurship. 
Normality Test Result Data

Assessment of normality (Group number 1)

\begin{tabular}{|l|llllll|}
\hline Variable & min & Max & Skew & c.r. & kurtosis & c.r. \\
\hline Int6 & 2.000 & 5.000 & -.098 & -.400 & -.741 & -1.513 \\
Int5 & 2.000 & 5.000 & -.044 & -.180 & -.590 & -1.204 \\
Int4 & 1.000 & 5.000 & -.300 & -1.225 & -.713 & -1.455 \\
Edu6 & 1.000 & 5.000 & -.186 & -.757 & -.495 & -1.011 \\
Edu5 & 1.000 & 5.000 & -.626 & -2.554 & -.155 & -.316 \\
Emo4 & 2.000 & 5.000 & -.157 & -.639 & -.749 & -1.529 \\
Edu4 & 1.000 & 5.000 & -.269 & -1.096 & -.538 & -1.098 \\
Edu3 & 1.000 & 5.000 & -.426 & -1.740 & -.573 & -1.169 \\
Edu2 & 1.000 & 5.000 & -.196 & -.799 & -.782 & -1.596 \\
Int3 & 1.000 & 5.000 & -.181 & -.737 & -1.036 & -2.115 \\
Int2 & 2.000 & 5.000 & -.014 & -.057 & -.903 & -1.844 \\
Att5 & 2.000 & 5.000 & -.222 & -.905 & -.926 & -1.891 \\
Emo3 & 2.000 & 5.000 & -.210 & -.858 & -.794 & -1.621 \\
Emo2 & 2.000 & 5.000 & -.139 & -.569 & -.997 & -2.036 \\
Edu1 & 2.000 & 5.000 & -.122 & -.497 & -.840 & -1.716 \\
Emo1 & 1.000 & 5.000 & -.402 & -1.641 & -.532 & -1.086 \\
Att4 & 1.000 & 5.000 & -.137 & -.558 & -.897 & -1.831 \\
Att1 & 2.000 & 5.000 & -.216 & -.883 & -.860 & -1.756 \\
Att2 & 2.000 & 5.000 & -.218 & -.891 & -.762 & -1.555 \\
Att3 & 2.000 & 5.000 & -.055 & -.224 & -1.073 & -2.190 \\
Int1 & 2.000 & 5.000 & -.092 & -.376 & -.495 & -1.011 \\
Multivariate & & & & & 37.419 & 6.020 \\
\hline
\end{tabular}

Source: Appendix 3 data is processed

Outliers are observations that have unique characteristics that look very different from other observations and appeared in the form of extreme good value for a single variable or variables combination (Ferdinand, 2002: 97). The treatment of outliers is carried out depends on how the outliers appear. Evaluation outliers include an analysis of univariate and multivariate outliers outliers.

table 4.3

Descriptive statistics Z-Score 


\begin{tabular}{|c|c|c|c|c|c|}
\hline \multicolumn{6}{|c|}{ Descriptive Statistics } \\
\hline & $\mathrm{N}$ & Minimum & Maximum & Mean & $\begin{array}{c}\text { Std. } \\
\text { Deviation }\end{array}$ \\
\hline Zscore(Edu1) & 100 & -1.69168 & 1.52037 & .0000000 & 1.000000 \\
\hline Zscore(Edu2) & 100 & -2.50595 & 1.53591 & .0000000 & 1.000000 \\
\hline Zscore(Edu3) & 100 & -2.65163 & 1.52416 & .0000000 & 1.000000 \\
\hline Zscore(Edu4) & 100 & -2.52051 & 1.48030 & .0000000 & 1.000000 \\
\hline Zscore(Edu5) & 100 & -2.69710 & 1.45228 & .0000000 & 1.000000 \\
\hline Zscore(Edu6) & 100 & -2.61323 & 1.40712 & .0000000 & 1.000000 \\
\hline Zscore(Emo1) & 100 & -2.68131 & 1.54123 & .0000000 & 1.000000 \\
\hline Zscore(Emoz) & 100 & -1.56792 & 1.46676 & .0000000 & 1.000000 \\
\hline Zscore(Emo3) & 100 & -1.72952 & 1.49319 & .0000000 & 1.000000 \\
\hline Zscore(Emo4) & 100 & -1.78482 & 1.52040 & .0000000 & 1.000000 \\
\hline Zscore(Att1) & 100 & -1.63706 & 1.53145 & .0000000 & 1.000000 \\
\hline Zscore(Att2) & 100 & -1.73699 & 1.51987 & .0000000 & 1.000000 \\
\hline Zscore(Att3) & 100 & -1.50517 & 1.46556 & .0000000 & 1.000000 \\
\hline Zscore(Att4) & 100 & -2.45770 & 1.42799 & .0000000 & 1.000000 \\
\hline Zscore(Att5) & 100 & -1.63009 & 1.44555 & .0000000 & 1.000000 \\
\hline Zscore $(\operatorname{Int} 1)$ & 100 & -1.92984 & 1.73441 & .0000000 & 1.000000 \\
\hline Zscore(Int2) & 100 & -1.56128 & 1.60348 & .0000000 & 1.000000 \\
\hline Zscore (Int3) & 100 & -2.37897 & 1.33817 & .0000000 & 1.000000 \\
\hline Zscore(Int4) & 100 & -2.62589 & 1.36786 & .0000000 & 1.000000 \\
\hline Zscore $(\operatorname{Int} 5)$ & 100 & -1.80782 & 1.73693 & .0000000 & 1.000000 \\
\hline Zscore (Int6) & 100 & -1.66808 & 1.69047 & .0000000 & 1.000000 \\
\hline Valid $N$ (listwise) & 100 & & & & \\
\hline
\end{tabular}

Source: Appendix 3 data is processed

Testing for the presence of univariate outliers can be done by determining the threshold value that would be categorized as outliers by converting the value of research data in standard score or so-called z-score, which has an average of zero with a standard deviation of one. For large samples (over 100 observations), evaluation guidelines is that the threshold value of the $\mathrm{z}$-score is in the range 3 to 4 (Ferdinand, 2002: 98). Based on the results of the conversion to a $\mathrm{z}$-score values in Table 4.3. seen that the maximum and minimum values of all variables are smaller than 4 , so there are no univariate outliers in the data.

Evaluation of the multivariate outliers needs to be done, because although the data analyzed showed no outliers in univariate level, these observations may be an outlier when it has been combined with each other. This evaluation is done through the test Mahalanobis Distance. Mahalanobis Distance shows the distance of an observation than the average of all variables in a multidimensional space (Ferdinand 2002: 102). This test is performed using Mahalanobis Distance criteria at the level of $\mathrm{p}<0.001$. Mahalanobis Distance is evaluated using $\square 2$ the degrees of freedom of the number of indicators used in the study, which is 21 . So in this study, when the Mahalanobis Distance is larger than $\square 2(21,0.001)$ $=46797$, the data that is multivariate outliers.

Table

\begin{tabular}{|l|lll|}
\hline Observation number & Mahalanobis d-squared & $\mathrm{p} 1$ & $\mathrm{p} 2$ \\
\hline 97 & 64.795 & .000 & .000 \\
24 & 47.069 & .001 & .004 \\
26 & 38.422 & .011 & .109 \\
17 & 35.856 & .023 & .193 \\
100 & 34.970 & .028 & .157 \\
56 & 33.458 & .041 & .234 \\
30 & 33.368 & .042 & .131 \\
99 & 32.413 & .053 & .163 \\
22 & 31.865 & .060 & .151 \\
\hline
\end{tabular}




\begin{tabular}{|l|lll|}
\hline Observation number & Mahalanobis d-squared & $\mathrm{p} 1$ & $\mathrm{p} 2$ \\
\hline 29 & 31.323 & .068 & .147 \\
52 & 31.141 & .071 & .100 \\
61 & 31.032 & .073 & .061 \\
11 & 30.965 & .074 & .034 \\
25 & 29.874 & .095 & .088 \\
7 & 29.318 & .107 & .110 \\
\hline
\end{tabular}

Source: Appendix 3 data is processed

In Table, it appears that the Mahalanobis Distance lowest value is 1900 and the highest was 60254 . So we can conclude that there are no multivariate outlier.

table 4.5

Mahalanobis Distance

\begin{tabular}{|c|c|c|c|c|c|}
\hline \multicolumn{6}{|c|}{ Residuals Statistics $^{a}$} \\
\hline & Minimum & Maximum & Mean & $\begin{array}{c}\text { Std. } \\
\text { Deviation }\end{array}$ & $\mathrm{N}$ \\
\hline Predicted Value & 17.04 & 109.89 & 50.50 & 16.726 & 100 \\
\hline Std. Predicted Value & -2.001 & 3.551 & .000 & 1.000 & 100 \\
\hline $\begin{array}{l}\text { Standard Error of } \\
\text { Predicted Value }\end{array}$ & 7.724 & 21.662 & 12.333 & 2.201 & 100 \\
\hline Adjusted Predicted Value & 14.40 & 134.70 & 50.85 & 19.076 & 100 \\
\hline Residual & -50.136 & 50.493 & .000 & 23.704 & 100 \\
\hline Std. Residual & -1.877 & 1.891 & .000 & .888 & 100 \\
\hline Stud. Residual & -2.258 & 2.141 & -.005 & 1.001 & 100 \\
\hline Deleted Residual & -72.529 & 65.596 & -.351 & 30.365 & 100 \\
\hline Stud. Deleted Residual & -2.321 & 2.193 & -.003 & 1.009 & 100 \\
\hline Mahal. Distance & 7.291 & 64.147 & 20.790 & 8.316 & 100 \\
\hline Cook's Distance & .000 & .104 & .013 & .017 & 100 \\
\hline $\begin{array}{l}\text { Centered Leverage } \\
\text { Value }\end{array}$ & .074 & .648 & .210 & .084 & 100 \\
\hline
\end{tabular}

a. Dependent Variable: Obs

Source: Appendix 3 data is processed

Multikolinearitas can be detected from the determinant of the covariance matrix. Covariance matrix determinant value is very small to give an indication of the problem of multicollinearity or singularity (Ferdinand, 2002: 109). In the AMOS program, the application will immediately give a warning if there is a singularity in the covariance matrix. The covariance matrix determinate. Determinant of sample covariance matrix $=$ 3,456

From the test results obtained AMOS that the determinant of the covariance matrix $=3,456$ which is far from zero. So we can conclude there is no evidence of multicollinearity or singularity in a combination of variable data, so that this data can be analyzed further.

Once a model is created, the data for model testing has been collected and inputted, as well as a number of assumptions have been met, then the next stage is to test the model amos or measurement models. Measurement models are part of SEM models consisting of latent variables (constructs) and some manifest variables (indicators). The purpose of 
testing is to determine how precise the manifest variables can explain existing latent variables. The test results can be seen in Figure 4.5 and Table 4.6.

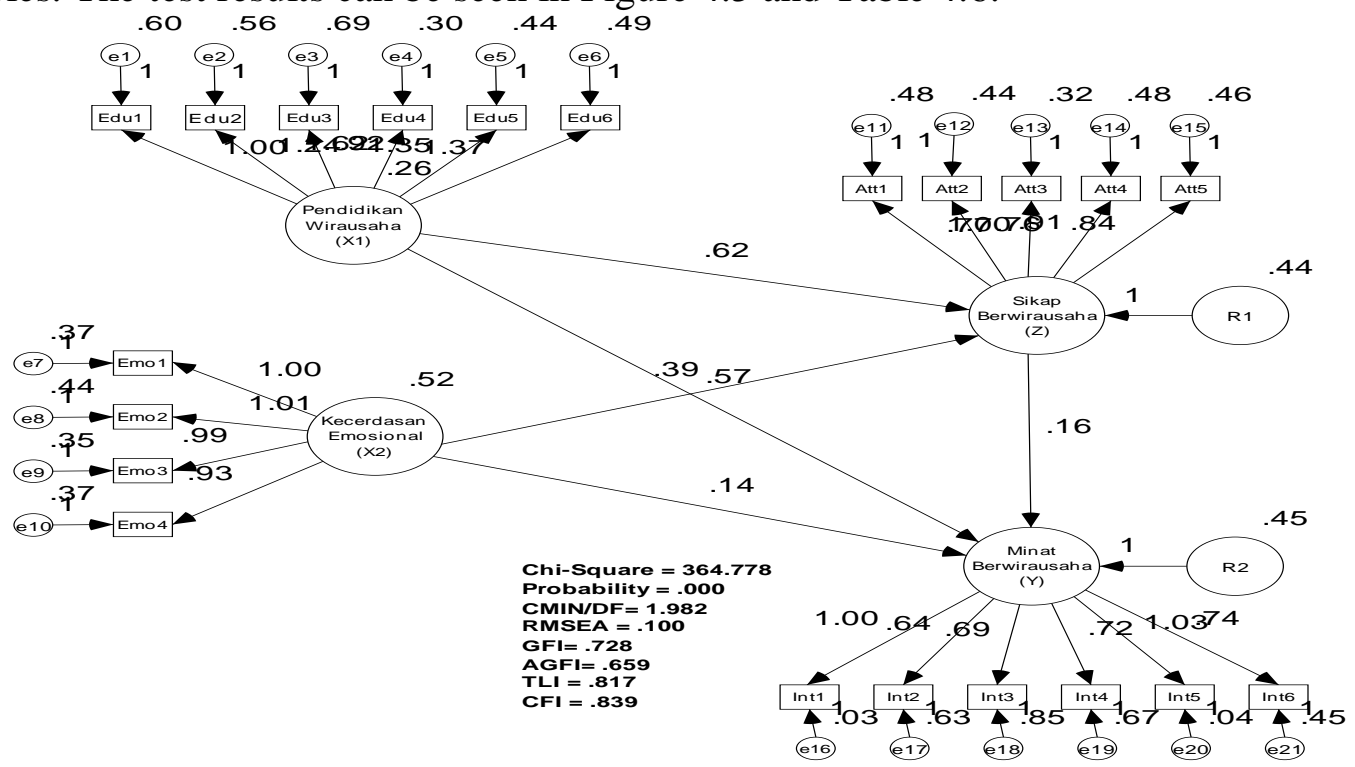

Figure 4.5 Measurement Model Before Codification

Source: Appendix 3 data processing results with Amos 7:00, 2017

table 4.6

Evaluation Criteria Goodness of Fit Indices Before Modification Model

\begin{tabular}{|l|l|l|l|}
\hline Criteria & results & value & Model \\
\hline Chi-Square & 364.778 & $\chi^{2}$ tabel & Does'n meet \\
\hline CMIN/DF & 1.982 & $\leq 2,00$ & Meet \\
\hline Probability & 0.000 & $\geq 0,05$ & Does'n meet \\
\hline RMSEA & 0.100 & $\leq 0,08$ & Does'n meet \\
\hline GFI & 0.728 & $\geq 0,90$ & Does'n meet \\
\hline AGFI & 0.659 & $\geq 0,90$ & Marginal Fit \\
\hline TLI & 0.817 & $\geq 0,95$ & Marginal Fit \\
\hline CFI & 0.839 & $\geq 0,94$ & Marginal Fit \\
\hline
\end{tabular}

Source: Data processing by Amos 7:00, 2017

The results of SEM model calculations produce an index goodness of fit as shown in Table 4.7. Based on Table 4.7, it can be seen that the value of chi-squares and probability showed poor results as well. However, the value of chi-squares are very sensitive to the sample size, and the value of RMSEA is less good. Therefore, it is advisable to carry out modification SEM models. Modification SEM model results can be seen in Figure 4.6 and Table 4.7

The results of SEM model calculations produce an index goodness of fit as shown in Table 4.7. Based on Table 4.7, it can be seen that the value of chi-squares and probability showed poor results as well. However, the value of chi-squares are very sensitive to the sample size, and the value of RMSEA is less good. Therefore, it is advisable to carry out 
modification SEM models. Modification SEM model results can be seen in Figure 4.6 and Table 4.7

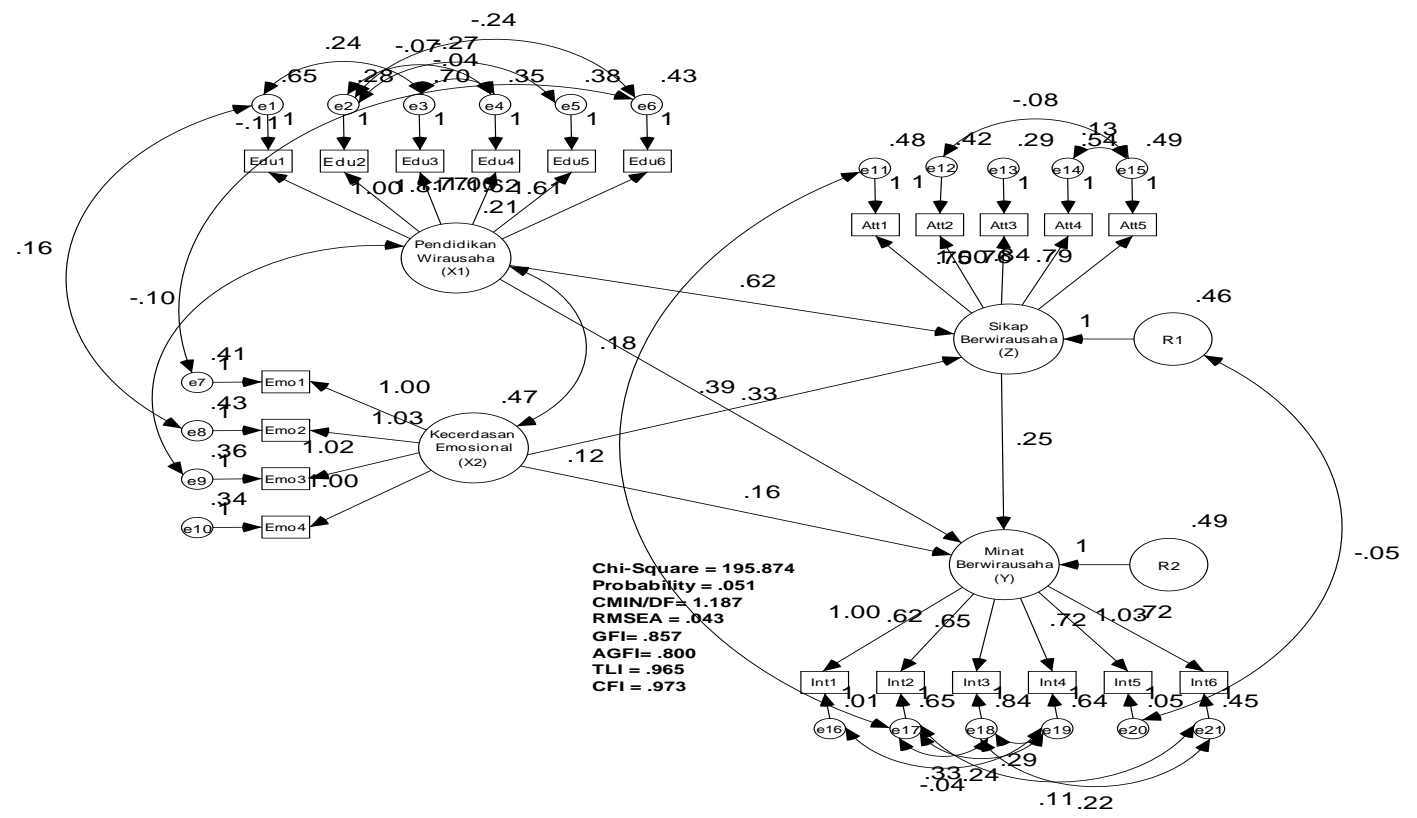

Figure 4.6 Measurement Model

Source: Appendix 3 data processing results with Amos 7:00, 2017

Hypothesis Testing Results

\begin{tabular}{|c|c|c|c|c|c|c|}
\hline & & Estimate & S.E. & C.R. & $\mathrm{P}$ & Ket \\
\hline$(Z)$ & $<---\quad(X 1)$ & .620 & .246 & 2.521 & .012 & Sig \\
\hline Z) & $<---\quad(X 2)$ & .390 & .157 & 2.482 & .013 & Sig \\
\hline (Y) & $<---\quad(X 1)$ & .328 & .238 & 1.377 & .168 & Sig \\
\hline$(\mathrm{Y})$ & $<---\quad(X 2)$ & .158 & .156 & 1.013 & .311 & Sig \\
\hline (Y) & <--- $\quad(Z)$ & .251 & .122 & 2.054 & .040 & Sig \\
\hline
\end{tabular}

Source: Appendix 3 data is processed

1. Entrepreneurship Education (X1) significantly affects the attitude of Entrepreneurship (Z). This is evident from the path marked positive coefficient of 0.620 with a value C.R. amounting to 2,521 and obtained a significance probability (p) of 0.012 which is smaller than the significance level $(\square)$ determined at 0.05. Thus Entrepreneurship Education Entrepreneurship significant effect on attitude. So the first hypothesis, which reads: "Suspected Entrepreneurship Education Entrepreneurship significantly influence the attitude of the generation $\mathrm{Y}^{\prime}$ is proven.

2. Emotional Intelligence (X2) significantly affects the attitude of Entrepreneurship (Z). This is evident from the path marked positive coefficient of 0.390 with a value C.R. amounting to 2,482 and obtained a significance probability (p) of 0.013 which is smaller than the significance level $(\square)$ determined at 0.05. Thus Emotional Intelligence 
influence the attitude Berwirausahasebesar 0.390, which means that every increase in Emotional Intelligence will raise the entrepreneurship attitude of 0.390 . So the second hypothesis, which reads: "Suspected of emotional intelligence significantly influence entrepreneurial attitude Generation $\mathrm{Y}^{\prime \prime}$ is proven.

3. Entrepreneurship Education (X1) had no significant effect on the interests of Entrepreneurship (Y). This is evident from the path marked positive coefficient of 0.328 with a value C.R. amounting to 1,377 and obtained a significance probability (p) of 0.168 greater than the significance level determined at 0.05 . So the third hypothesis, which reads: "Entrepreneurship Education Suspected significant effect on entrepreneurship Interests generation $\mathrm{Y}^{\prime \prime}$ is not proven.

4. Emotional Intelligence (X2) had no significant effect on the interest in entrepreneurship (Y). This is evident from the path marked positive coefficient of 0.158 with a value C.R. amounting to 1,013 and obtained a significance probability (p) of 0.311 greater than the significance level determined at 0.05 . So the fourth hypothesis, which reads: "Suspected of Emotional Intelligence significant effect on entrepreneurship Interests generation Y" is not proven.

5. Attitude Entrepreneurship (Z) significantly affects the interest in entrepreneurship (Y). This is evident from the path marked positive coefficient of 0.251 with a value C.R. amounting to 2,054 and obtained a significance probability (p) of 0,040 smaller than the significance level determined at 0.05 . Thus Berwirausahaberpengaruh attitude towards Interests berwirausahasebesar 0.251, which means that every increase in Berwirausahamaka attitude will increase interest in entrepreneurship at 0.251 . So the fifth hypothesis, which reads: "Suspected Attitudes Entrepreneurship significant effect on entrepreneurship Interests generation $\mathrm{Y}^{\prime}$ is proven.

\section{CONCLUSION}

Based on the overall results of the study, and the conclusions, obtained, can be developed several suggestions for the parties, which berkepenting $\neg$ an in this study. The suggestions put forward, as follows:

1. It is expected that the results of research into teacher evaluation for the lack of influence of entrepreneurship education and emotional intelligence to the interest in entrepreneurship Y generation, which indirectly have an impact on entrepreneurial learning innovation.

2. It is hoped that future studies as a discourse and literature in particular to the discussion the influence of entrepreneurship education and emotional intelligence to the interest in entrepreneurship through entrepreneurial attitude on the $\mathrm{Y}$ generation, in order to research results obtained.

\section{REFERENCES}

Andika \& Iskandarsyah. (2012). Analisis Pengaruh Sikap, Norma Subyektif Dan Efikasi Diri Terhadap Intensi Berwirausaha Pada Mahasiswa Fakultas Ekonomi Universitas Syiah Kuala (Studi Pada Mahasiswa Fakutas Ekonomi Universitas Syiah Kuala). Eco Entrepreneurship Seminar \& Call for Paper "Improving Performance by Improving Environment. 
Barnawi (2012). School Preneurship.Yogyakarta:Ar-Ruzz Media

Depdiknas, Baitbang. 2007. Optimalisasi Peran LMPM dan P3G dalam peningkatan Mutu Pendidikan di Indonesia. Jakarta: Depdiknas.

Ferdinand \& Augusty.(2002). Structural Equation Modelling dalam Penelitian Manajemen. Semarang: FE UNDIP.

Firmansyah, Anang Haris, dkk. (2016). The Effect of Adversity Quotient and Entrepreneurial Self-Efficacy on Entrepreneurial Intention Through Entrepreneurial Attitude. IOSR Journal of Business and Management (IOSRJBM) e-ISSN: 2278-487X, p-ISSN: 2319-7668. Volume 18, Issue 5 .Ver. I (May. 2016), PP 45-55.

Golemen, Daniel.(2003). Working With Emotional Intelligence. (Terjemahan Alex Tri Kancono Widodo). PT. Gramedia : Jakarta.

Henn, S.,S.Koch, K.Doerner,C. dkk. (2009). Metahcuristics for the Order Batching Problem in Manual Order Picking Systems. Working Paper 20/2009, Faculty of Economics and Management, Otto von Guericke University Magdeburg.

Hurlock, E. (1980). Developmental Psychology: A life span approach. (5th ed). New Delhi: McGraw-Hill.

Kamsir, (2013). Kewirausahaan, Edisi revisi Jakarta: Grafindo.

Kolveroid, L., Moen, O.(1997). Entrepreneurship among business graduates : Does a major in entrepreneurship make a difference?, Journal of European Industrial Training, 21, 4, 154-160.

Kuusik, A. and Varblane, U., (2010). How to avoid customers leaving: the case of the Estonian telecommunication industry. Baltic Journal of Management, 4 (1), 6679.

Lee, S.H. \& Wong, P.K. (2004). An Exploratory Study of Technopreneurial Intentions: A Career Anchor Perspective. Journal of Business Venturing, 19(1): 728.

Lestari \& Sumantadinata (2013). Strategi peningkatan daya saing tuna olahan Indonesia di pasar internasional (Strategy for increasing the competitiveness of Indonesian processed tuna in the international market). Manajemen IKM: Jurnal Manajemen Pengembangan Industri Kecil Menengah 8(1): 36-44.

Liñán, F. \& Chen, Y. (2006). Testing the entrepreneurial intention model on a two-country sample. Available online at:http://www.recercat.net/bitstream/2072/2213/1/ UABDT06-7 .pdf (accessed 28 August 2007).

Liñán, \& Rueda-Cantuche, J. M. (2011). Factors affecting entrepreneurial intention levels. A role for education. International Entrepreneurship \& Management Journal, 7, 195-218.

Loudon, D L,\& Della Bitta, A J, (1993). Consumer Behaviour:Concepts and Application, Singapore:Mc.Grow-Hill, Inc.

Maholtra, Naresh K. (2009). Marketing Research: An Applied Orientation, fourth edition. Jakarta. PT Indeks.

Ni, Lee Wei, at.al. (2012). "Entrepreneurial Intention: A Study Among Students of Higher Learning Institution”, Bachelor of Business Administration, Universiti Tunku Abdul Rahman, Faculty of Business and Finance Department of Business. 
Packham, \& Thomas dkk. (2010). E-learning and retention: Key factors influencing student withdrawal. Education and Training, 46(6/7), 335-342.

Pulka, 2015. The Effects of Entrepreneurship Education on University Students' Attitude and Entrepreneurial Intention. European Journal of Business and Management ISSN 2222-1905 (Paper) ISSN 2222-2839 (Online) Vol.7, No.20, 2015

Santoso, Singgih. (2012). SPSS Statistik Parametrik. Jakarta: Penerbit PT. Elex Media Komputindo. 